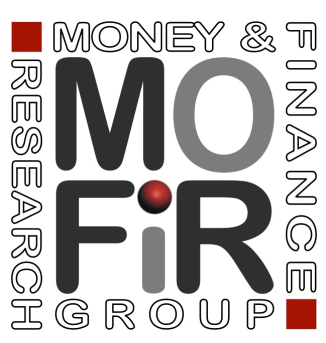

DOES FAMILY OWNERSHIP STRUCTURE AFFECT INVESTMENT-CASH FLOW SENSITIVITY?

EVIDENCE FROM ITALIAN SMES

Valentina Peruzzi

Working paper no. 112

September 2015 


\title{
Does family ownership structure affect investment-cash flow sensitivity? Evidence from Italian SMEs
}

\author{
Valentina Peruzzi \\ Department of Economic and Social Sciences \\ Università Politecnica delle Marche \\ P.le Martelli 8, 60121 Ancona, Italy \\ E-mail: v.peruzzi@univpm.it
}

\begin{abstract}
The aim of this paper is to investigate the impact of family control, family management and family ownership concentration on the investment-cash flow sensitivity of small- and medium-sized enterprises (SMEs). By analysing a sample of Italian small businesses for the period 2004-2013, I find that family owned firms have significantly larger investment-cash flow dependence with respect to their non-family counterparts. However, the adverse effect of family ownership on the sensitivity of investment spending to internal funds availability is mainly due to the presence of family CEOs and highly concentrated family ownership. Further robustness tests confirm the validity of the investmentcash flow sensitivity as proxy for the existence of financing constraints.
\end{abstract}

Keywords: family firms, investment-cash flow sensitivity, financing constraints, family managers.

JEL codes: G31, G32. 


\section{Introduction}

In perfect capital markets, firms' investment decisions are independent from their financial structure, companies can always substitute external financing for internal funds, and capital rationing does not exist (Modigliani and Miller, 1958). However, since capital markets are not perfect and an easier access to external finance for those companies with good investment opportunities may impact positively on economic development and growth, several empirical and theoretical studies have analyzed the determinants of firms' investment decisions and, most notably, the factors affecting the sensitivity of investment spending to internal funds availability.

Among the other variables, a large part of the current literature has focused the attention on the role played by companies' ownership and governance structure in mitigating or exacerbating the investment-cash flow dependence (Hoshi et al., 1991; Oliner and Rudebusch, 1992; Schaller, 1993; Hadlock, 1998; Schiantarelli and Sembenelli, 2000; Goergen and Renneboog, 2001; Pawlina and Renneboog, 2005). Given the widespread diffusion of family control, in particular, some recent empirical studies have investigated the impact of family ownership on the sensitivity of investment spending to internal funds availability. However, the provided evidence is still mixed. Andres (2011) and Pindado et al. (2011) indicate that large publicly traded family firms are not more susceptible to external financing constraints with respect to their non-family counterparts, as their investment outlays are consistently less dependent to internal capital. Conversely, Hung and Kuo (2011) find that family control increases the investment-cash flow sensitivity of listed corporations, due to asymmetric information problems. Although the existence of financing constraints is a greater concern for small and medium-sized enterprises than for large listed corporations, the presented findings entirely refer to publicly traded companies.

In order to fill this gap and provide conclusive results about the impact of family ownership on the investment-cash flow sensitivity, in this study I investigate whether family firms differ from their non-family counterparts in terms of investment-cash flow dependence by analyzing a sample of Italian SMEs. As different ownership and governance structures are shown to significantly affect the sensitivity of investment spending to internal funds availability, I also examine whether family management and highly concentrated family ownership influence investment-cash flow dependence. Finally, to test the validity of the investment-cash flow sensitivity as a proxy for the existence of financing constraints, I analyze whether financially constrained companies have higher investment-cash flow dependence.

Due to the high fraction of wealth invested in the company and their longer investment horizon, family owners are usually highly risk averse in their investment decisions, with 
beneficial consequences on both cost and availability of external financing (Bopaiah, 1998; Anderson et al., 2003; D'Aurizio et al., 2015; Stacchini and Degasperi, 2015). However, as largely indicated by the current literature, family businesses are significantly associated with greater agency conflicts in the controlling-minority shareholders relationship: family owners, especially in family-run and highly concentrated firms, have both the incentives and the power to take actions that benefit the family, at the detriment of other investors and company's operational efficiency (Bertrand and Schoar, 2006). Therefore, family firms' ability to attract external financing may be reduced. Finally, and more general, controlling families are often unwilling to finance their investment projects through too external debt financing or new equity issues, as they wish to maintain their control rights and pass a financially stable company onto future generations (Gallo and Vilaseca, 1996; McConaughy and Phillips, 1999; Lopez-Gracia and Sanchez-Andujar, 2007). Hence, their investment spending is expected to be deeply dependent from internal funds availability.

Given this background, I test the following hypotheses: (H1) Family ownership increases investment-cash flow sensitivity in SMEs; $(\mathrm{H} 2)$ The higher investment-cash flow sensitivity of family businesses, as compared to non-family firms, is mainly due to the presence of family CEOs and concentrated ownership.

To test these hypotheses, I analyze the investment-cash flow sensitivity of 926 Italian SMEs for the period 2004-2013, by drawing data from two deeply detailed sources of information: (i) the Survey on Italian Manufacturing Firms, carried out by UniCredit (and previously by MedioCredito Centrale-Capitalia); (ii) the BvD-AIDA database. From the Survey on Italian Manufacturing Firms, I gather both qualitative and quantitative information about firms' ownership and management structure, which are used to define family and non-family owned businesses; from BvD-AIDA, I recover balance-sheet data for all the companies under analysis for the period 2004-2013.

As concerns the empirical approach, I use as a basic investment regression model the one adopted by Fazzari et al. (1988). Unlike their specification, however, I include a broader set of firm specific controls accounting for companies' financial conditions and ownership structure characteristics. In order to eliminate unobservable heterogeneity and to account for endogeneity problems, I use panel data methodology and the generalized method of moments (GMM) estimation technique.

By way of preview, estimation results indicate that family owned firms are characterized by higher investment-cash flow sensitivities in comparison with their non-family counterparts. Further analyses, however, demonstrate that the greater dependence of investment spending to internal funds availability of family businesses is mainly due to the presence of both family CEOs and highly concentrated ownership structure. Family companies run by professional 
managers and family businesses with low ownership concentration, in fact, have nonsignificant investment-cash flow sensitivities. These findings, robust to different model specifications, strongly support both the theoretical hypotheses. Additional tests about the validity of the investment-cash flow sensitivity as proxy for the existence of financing constraints, finally, confirm Fazzari et al. (1988)'s view: investment-cash flow dependence is a proper measure for the presence of financing difficulties.

In providing this evidence, my research contributes to different fields of the current literature. First, I contribute to the investment-cash flow sensitivity studies by analyzing whether family ownership influences the dependence of investment spending to internal funds availability in the context of small unlisted firms, rather than large listed corporations. In this way, I complement the recent findings provided by Becchetti et al. (2010), D'Espallier and Guariglia (2015) and La Rocca et al. (2015). Second, to the best of my knowledge, this is the first research investigating the role of family management in mitigating or exacerbating investment-cash flow dependence. Hence, I contribute to the literature about the impact of ownership and governance structures on investment decisions (Hoshi et al., 1991; Hadlock, 1998; Goergen and Renneboog, 2001; Pawlina and Renneboog, 2005). Third, by testing the Kaplan and Zingales (1997) criticism, I provide significant evidence supporting the validity of the investment-cash flow sensitivity as proxy for the existence of financing constraints.

The evidence provided in this study also contributes to the growing family firm literature. Unlike previous researches (Andres, 2011; Hung and Ku, 2011; Pindado et al., 2011), for the first time I focus on investment-cash flow sensitivity of small- and medium- sized family businesses. By finding that family ownership, and especially family management, increase the dependence of investment spending to internal funds availability, I demonstrate that small family firms are more likely to suffer from financing constraints in comparison to their nonfamily counterparts.

Finally, as my research concentrates on Italy, where the percentages of both small businesses and family owned companies are particularly high, the practical implications of my results may be easily extended to other continental European countries.

The remainder of the paper is organized as follows. Section 2 reviews the current literature on the investment-cash flow sensitivity and presents the theoretical hypotheses that will be tested. Section 3 describes the data and the econometric method used to perform the empirical analysis. Section 4 discusses the main results of the investigation and presents the related robustness checks. Section 5 provides some concluding remarks.

\section{Background Literature}


Since the seminal work of Fazzari et al. (1988), which have documented the existence of a positive dependence of investment spending to internal funds availability for those companies suffering from more intense financing constraints, several empirical and theoretical studies have gradually associated the analysis of the investment-cash flow sensitivity to different corporate governance perspectives.

Schiantarelli and Sembenelli (2000), Goergen and Renneboog (2001) and Pawlina and Renneboog (2005), have been among the first to investigate the effect of highly concentrated ownership on the dependence of investment spending to internal funds availability. By examining firms' investment behavior in different European countries, their results strongly confirm the relevance of widespread ownership and large institutional blockholders in alleviating investment-cash flow dependence and financing constraints.

Due to the prevalent diffusion of family owned businesses all around the world, the empirical literature has recently focused on the analysis of family businesses' investment policies, and especially, on their investment-cash flow sensitivities. Despite the extensive research, however, the provided evidence remains still controversial. Andres (2011) and Pindado et al. (2011) by analyzing respectively German and European companies, indicate that publicly traded family firms are not more likely to suffer from financing constraints with respect to their non-family counterparts, as their investment behavior is substantially less dependent to internal funds availability. On the contrary, Gugler (2003) and Hung and Kuo (2011), who examine Austrian and Taiwanese listed corporations, suggest that family ownership has an adverse effect on firms' investment-cash flow sensitivities, as asymmetric information problems associated with family owned businesses significantly increase the dependence of investment spending to cash flow.

Although investment spending of large listed companies should be less affected by internal funds availability than the investment outlay of small unlisted firms, the described evidence entirely refer to publicly traded corporations. The intrinsic characteristics largely associated with founding family control structures, moreover, may be more relevant for small businesses' decisions and evolution than for large and widely held listed corporations.

Due to the high fraction of wealth invested in the company, their longer investment horizon, and their survival and reputation concerns, family owners are usually highly risk averse in their investment policies. In particular, by reducing moral hazard incentives, they are found to be significantly associated with lower cost of financing and better access to finance (Bopaiah, 1998; Anderson et al., 2003; D’Aurizio et al., 2015; Stacchini and Degasperi, 2015). In spite of that, controlling families are often unwilling to finance their investment projects through too external debt financing or new equity issues, as they wish to maintain 
their control rights and pass a financially stable company onto future generations (Gallo and Vilaseca, 1996; McConaughy and Phillips, 1999; Lopez-Gracia and Sanchez-Andujar, 2007). Hence, their investment spending is expected to be deeply dependent from internal funds availability.

As largely indicated by the current literature, moreover, family businesses are usually characterized by larger agency conflicts in the controlling-minority shareholders relationship, especially when family members are hired as CEOs or family ownership results to be highly concentrated. Family owners, in fact, by owning higher shares of cash flow rights, may have the incentives and the power to divert resources out of the company at the detriment of both other investors and firm's profitability (Bertrand and Schoar, 2006). In this context, family businesses' ability to attract external financing may be obviously reduced.

Hence, I test the following hypotheses:

H1: Family ownership increases investment-cash flow sensitivity in SMEs.

$\mathrm{H} 2$ : The higher investment-cash flow sensitivity of family businesses, as compared to nonfamily firms, is mainly due to the presence of family CEOs and concentrated ownership.

\section{Data and Method}

Data sources and sample selection

To build the dataset used in the empirical analysis, I draw information from two main sources: (i) the 10th wave of the Survey on Italian Manufacturing Firms (SIMF); (ii) the BvD-AIDA database.

The Survey on Italian Manufacturing Firms, conducted every three years by UniCredit (and previously by MedioCredito Centrale-Capitalia), collects detailed information about firm's ownership and governance structure, workforce characteristics, attitude to invest and innovate, extent of internationalization and export activities, financial conditions and lending relationships. The 10th wave of the survey, which provides information for the period 20042006, consists of 5137 Italian enterprises. All the companies with more than 500 employees are included in the sample, while those having a number of employees in the range 11-500 are sampled according to a stratified selection procedure based on their size, sector, and 
geographic localization ${ }^{1}$. Since my analysis focuses on small- and medium-sized enterprises, following the European Commission definition of SMEs, I exclude from the whole sample those companies with more than 250 employees and 43 million euro of total assets. Then, for the remaining companies, I recover balance sheet data for the period 2004-2013 from the BvD-AIDA database, the most comprehensive source of financial information for Italian corporations. Accounting for missing data, I finally end up with a balanced panel comprised of 926 SMEs (9260 observations).

The distribution of the final sample by industry sector, ownership type and geographical location is reported in Table 1.

Family firms classification

Despite the widespread literature on family businesses, there is not a clear consensus on how family firms should be defined. Theoretical and empirical studies ground on definitions based on ownership shares, family involvement in the business, and some combinations of the two criteria (La Porta et al., 1999; Faccio and Lang, 2002; Anderson and Reeb, 2003; Barontini and Caprio, 2006; Villalonga and Amit, 2006). In this study, in order to avoid getting distorted results due to the adoption of a subjective definition of family control, I employ firm selfreported information to distinguish between family and non-family owned companies. In particular, I rely on the following question of the Survey on Italian Manufacturing Firms:

\section{A7.1. Is your firm directly or indirectly controlled by an individual or a family-} owned entity?

In order to account for the potential heterogeneity of investment policies within the subsample of family owned businesses, furthermore, I use the detailed information provided by the Survey on Italian Manufacturing Firms to separate family firms run by family CEOs and family companies hiring professional managers. Specifically, I consider the following question:

A7.5. If your firm is family controlled, who is the CEO? (i) the individual who owns the firm or a member of the controlling family; (ii) a manager recruited from outside the firm; (iii) a manager appointed within the firm.

In line with the overall distribution of family businesses in Italy, Panel B of Table 1

\footnotetext{
${ }^{1}$ Overall, the surveyed firms cover almost 9 percent of the reference universe in terms of employees and about 10 percent in terms of value added. Thus, the sample is highly representative of the economic structure of the Italian manufacturing sector.
} 
indicates that about 60 percent of the companies included in the sample $(590 / 926 \approx 63.71$ percent) are family owned. Among them, 87 percent of firms result to be run by family CEOs, while 13 percent of businesses decided to hire professional managers external to the controlling families.

\section{Descriptive analysis}

In order to investigate the differences that exist between family and non-family owned firms, I carry out several difference of means tests for the main variables included in the multivariate analysis. While Panel A of Table 2 reports summary statistics for the full sample of companies, Panels $B, C$ and $D$ present the results of these univariate tests. In Panel $B, I$ simply differentiate between family and non-family owned firms; in Panels C and D I go a step further by dividing the family firm sample in different subgroups depending on the CEO type (Panel B) and the level of ownership concentration (Panel C).

As indicated by the $t$-statistics reported in column (5) of Panel B, family businesses significantly differ from their non-family counterparts. First, family firms have lower level of cash flow but, at the same time, face higher investment opportunities, as proxied by the growth rate of sales. This result suggests that family owned businesses are more likely to be financially constrained with respect to non-family owned companies. Moreover, because of their larger risk aversion, family firms are slightly less indebted and retain more cash and marketable securities, when compared to their counterparts. Finally, they show a higher investment ratio, but the difference with respect to the non-family firms subsample is not statistically significant.

The univariate tests presented in Panels $C$ and D of Table 2 show that family companies are not so heterogeneous in their investment policies as they partially differ from each other in terms of investment-cash flow sensitivities. As highlighted in Panel C, family businesses run by family CEOs own less internal capital but have higher investment opportunities (see tstatistics in column 5). Consistently with my Hypothesis 2, which posits that the higher investment-cash flow sensitivity of family firms may be due to the presence of family managers, these findings point out potential problems of financing constraints in family companies appointing family members as CEOs. On the contrary, as Panel D of Table 2 reports, family businesses are more homogeneous when they are distinguished on the basis of their ownership concentration. Although highly concentrated family firms invest less and have lower debt ratios with respect to family businesses with low ownership concentration, they do not significantly differ in terms of investment-cash flow sensitivities.

\section{Baseline specification}


To estimate the investment-cash flow sensitivity, I use as a basic investment regression model the one adopted by Fazzari et al. (1988):

$$
(I N V / K)_{i t}=\alpha_{0}+\beta_{1}(C F / K)_{i t}+\beta_{2} I O_{i t}+\varepsilon_{i t}
$$

where the dependent variable $(I N V / K)_{i t}$ is the ratio of corporate investments to the beginning of the year value of net fixed assets; $(C F / K)_{i t}$ is the cash flow measure and it is defined as net income plus depreciation allowances (normalized by the level of net fixed assets at the beginning of the year); $I O_{i t}$ are firms' investment opportunities; $\varepsilon_{i t}$ is the error term.

Most of the investment-cash flow sensitivity studies employ Tobin's marginal Q (usually proxied by the firm's market-to-book value) as a control for company's growth potential (Fazzari et al., 1988; Kaplan and Zingales, 1997; Andres, 2011; Pindado et al., 2011). However, since market values are usually not available for small unlisted firms, in this study, following D'Espallier and Guariglia (2015) and La Rocca et al. (2015), I include as investment opportunities proxy the growth rate of sales $\left(\triangle S A L E S_{i t}\right)$. As shown by these empirical works and predicted by the sales accelerator theory of investment (Abel and Blanchard, 1986), the demand for capital goods is directly and positively affected by the level of firm's output; therefore, I expect a positive and statistically significant coefficient.

The main objective of this research is to investigate whether family ownership mitigate or exacerbate the dependence of investment to cash flow. For this reason, I extend Fazzari et al.'s (1988) investment model by incorporating among the explanatory variables a dummy variable accounting for family ownership $\left(F A M_{-} F I R M_{i}\right)$ and its interaction with the cash flow control $\left((C F / K)_{i t} * F A M_{-} F I R M_{i}\right)$. The stand-alone family dummy allows to account for the direct effect of family ownership on investment spending (Anderson and Reeb, 2003; Anderson et al., 2012), while the interaction term disentangles the moderating effect of family control on the investment-cash flow sensitivity.

Despite the inclusion of the family firm dummy, the empirical analysis may lead to biased coefficients if other relevant firm characteristics are omitted. First, there is strong evidence that stock measures of firms' internal liquidity have an effect on investment spending, especially for those companies facing higher cost of external funds due to information problems in capital markets (Fazzari et al., 1988; Almeida et al., 2004; Andres, 2011). Second, the level of debt is shown to be an important determinant in the empirical investment literature (Goergen and Renneboog, 2001; Hung and Kuo, 2011). Hence, I include in the righthand side of the econometric specification both firms' cash holdings and debt ratios $\left(X_{i t-1}\right)$.

Finally, in order to account for the dynamics of the investment policy and to capture the 
accelerator effect of this corporate decision, I further modify Equation 1 by including the lag of the dependent variable $\left((I N V / K)_{i t-1}\right)$.

Hence, the baseline model used to test the basic proposition that family ownership increases the sensitivity of investment to cash flow (H1), results to be as follows:

$$
\begin{gathered}
(I N V / K)_{i t}= \\
\alpha_{0}+\beta_{0}(I N V / K)_{i t-1}+\beta_{1}(C F / K)_{i t}+\beta_{2} \Delta S A L E S_{i t}+\beta_{3} F A M_{-} F I R M_{i}+ \\
\gamma\left((C F / K)_{i t} * F A M_{-} F I R M_{i}\right)+\varphi X_{i t-1}+\varepsilon_{i t}(2)
\end{gathered}
$$

where the dependent variable $(I N V / K)_{i t}$ is the ratio of corporate investments to the beginning of the year value of net fixed assets; $(C F / K)_{i t}$ is net income plus depreciation allowances (normalized by the level of net fixed assets at the beginning of the year); $\triangle S A L E S_{i t}$ is the growth rate of sales; $F A M_{-} F I R M_{i}$ is a dummy variable equal to one if company $\mathrm{i}$ is family owned, and zero otherwise; $X_{i t-1}$ is a set of firm-specific controls; $\varepsilon_{i t}$ is the error term.

In this model, the effect of cash flow on investment is captured by $\beta_{1}$ for non-family firms (given FAM_FIRM $\left.M_{i}=0\right)$ and by $\left(\beta_{1}+\gamma\right)$ for family businesses. Therefore, in line with hypothesis 1 I expect $\left(\hat{\beta}_{1}+\hat{\gamma}\right)>\hat{\beta}_{1}$.

To test the second hypothesis and disentangle whether family management and high ownership concentration exacerbate investment-cash flow sensitivity in family owned firms, I modify the model in Equation 2. Specifically, I replace the family firm dummy with two new binary variables, FAMILY_CEO $\mathrm{O}_{i}$ and $\mathrm{HIGH}_{-} O W N E R S H I P_{i}$, which account, respectively, for the presence of a family manager and a highly concentrated family ownership. Equations $3 a$ and $3 \mathrm{~b}$ result to be as follows:

$$
\begin{gathered}
(I N V / K)_{i t}= \\
\alpha_{0}+\beta_{0}(I N V / K)_{i t-1}+\beta_{1}(C F / K)_{i t}+\beta_{2} \Delta S A L E S_{i t}+\beta_{3} F A M I L Y_{-} C E O_{i}+ \\
\gamma\left((C F / K)_{i t} * F A M I L Y_{-} C E O_{i}\right)+\varphi X_{i t-1}+\varepsilon_{i t} \\
(I N V / K)_{i t}= \\
\alpha_{0}+\beta_{0}(I N V / K)_{i t-1}+\beta_{1}(C F / K)_{i t}+\beta_{2} \Delta S A L E S_{i t}+\beta_{3} H I G H_{-} O W N E R S H I P_{i}+ \\
\gamma\left((C F / K)_{i t} * H I G H_{-} O W N E R S H I P_{i}\right)+\varphi X_{i t-1}+\varepsilon_{i t} \quad \text { (3b) }
\end{gathered}
$$

where the dependent variable $(I N V / K)_{i t}$ is the ratio of corporate investments to the beginning of the year value of net fixed assets; $(C F / K)_{i t}$ is net income plus depreciation 
allowances (normalized by the level of net fixed assets at the beginning of the year); $\triangle S A L E S_{i t}$ is the growth rate of sales; $F_{A M I L Y_{-} C E O_{i}}$ is a dummy variable equal to one if company $i$ is family run, and zero otherwise; HIGH_OWNERSHIP $i$ is a dummy variable equal to one if company $i$ has a highly concentrated ownership, and zero otherwise; $X_{i t-1}$ is a set of firm-specific controls; $\varepsilon_{i t}$ is the error term².

In this model, the effect of cash flow on investment is captured by $\beta_{1}$ for family firms with professional manager or non-concentrated ownership (given FAMILY_CEO $_{i}=0$ or HIGH_OWNERSHIP $\left.P_{i}=0\right)$ and by $\left(\beta_{1}+\gamma\right)$ for family businesses with family CEOs or highly concentrated ownership. Therefore, in line with hypothesis 2 I expect $\left(\hat{\beta}_{1}+\hat{\gamma}\right)>\hat{\beta}_{1}$.

In order to avoid getting biased estimates due to the unobservable heterogeneity problem and to account for the potential endogeneity of the explanatory variables, I use panel data methodology in the estimation of the model. Specifically, after estimating all the models through OLS and within-groups estimators, I perform both first difference and system GMM estimations. Given the dynamic nature of investment policies and the endogeneity characterizing firms' financial indicators, the GMM is particularly suitable for the study of the investment-cash flow sensitivity (Pindado and de la Torre, 2006; Pindado et al., 2011). Following previous empirical studies (Andres, 2011; Pindado et al., 2011), I use the lagged values of the explanatory variables as instruments in the GMM estimation, and I perform both the Arellano-Bond autocorrelation tests and the Hansen $J$ statistic of overidentifying restrictions to test for the absence of correlation between the instruments and the error term.

\section{Results}

The results obtained from the estimation of Equation 2 using the different estimators discussed in the previous section are reported in Table 4. Consistently with the current literature on investment-cash flow dependence, ols, within-groups, first difference GMM and system GMM estimations indicate a positive and statistically significant sensitivity of investment spending to internally generated funds for all the SMEs included in the sample. As their investment policies strictly depend on the available amount of internal capital, these companies probably face greater financing constraints.

The positive effect of internal funds on investment spending, however, is larger for family firms $\left(\hat{\beta}_{1}+\hat{\gamma}=0.063+0.203=0.266\right.$, statistically significant $)$ than for non-family owned businesses $\left(\hat{\beta}_{1}=0.063\right)$. Although cash flows positively and significantly affect investment

\footnotetext{
${ }^{2}$ Equations $3 \mathrm{a}$ and $3 \mathrm{~b}$ are estimated on the subsample of family owned companies.
} 
policies in non-family owned firms, the effect is substantially lower in comparison with their family counterparts. In line with the theoretical predictions discussed in Section II, these findings strongly support hypothesis 1 ( $\mathrm{H} 1$ ) and complement previous studies about the effect of family ownership on the investment-cash flow sensitivity of listed companies (Andres, 2011; Hung and Kuo, 2011; Pindado et al., 2011). In this particular case, the results suggest that family control adversely affects investment dynamics in small- and medium-sized enterprises by increasing the dependence of investment spending to internal funds availability.

Positive and statistically significant estimates of $\hat{\beta}_{2}$ indicate that, consistently with the current literature on the investment-cash flow sensitivity (Fazzari et al., 1988; Kaplan and Zingales, 1997), corporate investment is considerably dependent from companies' investment opportunities, as proxied by the growth rate of sales $\left(\triangle S A L E S_{i t}\right)$. The significance of this result also validates the use of sales growth as investment opportunities proxies in the analysis of small unlisted firms' investment policies, as already confirmed by D'Espallier and Guariglia (2015) and La Rocca et al. (2015).

With regard to the other explanatory variables included in the econometric specification, estimation results highlight a positive and significant relation between investment spending and both cash holdings $\left(\mathrm{CASH}_{i t-1}\right)$ and firm debt $\left(D E B T_{i t-1}\right)$.

In order to disentangle the effect of both family management and family ownership concentration on the investment-cash flow sensitivity, Equations $3 \mathrm{a}$ and $3 \mathrm{~b}$ are further estimated on the subsample of family owned companies. Ols, within-groups, first difference GMM and system GMM estimations, reported in Table 5 (columns (1)-(4)), show a positive and statistically significant effect of internal funds on investment spending for family firms run by family managers $\left(\hat{\beta}_{1}+\hat{\gamma}=0.047+0.223=0.270\right.$, statistically significant $)$, and a nonsignificant impact of cash flow on investment decisions of professionally run family businesses ( $\hat{\beta}_{1}=0.047$, no statistically significant). Similar results are provided in relation to the effect of family ownership concentration. As presented in columns (5)-(8), the investment-cash flow sensitivity is significantly larger for family firms with highly concentrated ownership ( $\hat{\beta}_{1}+\hat{\gamma}=$ $0.440+0.121=0.561$, statistically significant), than for family companies with more dispersed ownership concentration ( $\hat{\beta}_{1}=0.440$, no statistically significant).

In line with hypothesis $2(\mathrm{H} 2)$, these findings strongly support the idea that family management and highly concentrated ownership structure, by exacerbating agency conflicts in the controlling-minority shareholders relationship, adversely affects the dependence of investment to internal funds availability. As family businesses run by professional CEOs and family firms with widespread ownership concentration promote efficient investment policies, 
the negative impact of family control on investment-cash flow sensitivity is mainly due to the governance structure adopted by the company.

As for the estimation of Equation 2, also in this case regression results highlight a positive and statistically significant effect of the growth of sales variable $\left(\triangle S A L E S_{i t}\right)$, which again is found to be a good proxy for firms' investment opportunities. Consistently with the current literature on investment policies, I also find support for the relevant impact of cash holdings on investment decisions and for the monitoring role of debt (Hung and Kuo, 2011).

Robustness check: Investment-cash flow sensitivity and financing constraints

Since the study of Fazzari et al. (1988), a high investment-cash flow sensitivity has been interpreted as a sign of the existence of financing constraints. Kaplan and Zingales (1997) and several subsequent empirical works, however, demonstrate that increasing investment-cash flow dependence can characterize also those (listed) companies classified as financially unconstrained.

For the purpose of addressing the aforementioned criticism at least in relation to my empirical analysis, I check whether it is reasonable to exclude the possibility that in my sample $\delta(I N V / K)_{i t} / \delta(C F / K)_{i t}$ is lower for more financially constrained companies. To perform this test I first distinguish financially constrained and unconstrained firms by relying on the information provided by the Survey on Italian Manufacturing Firms. Specifically, I classify as financially constrained those companies answering "yes" to the following two questions:

F1.4. In 2006, would your firm have wished a larger amount of loans at the prevailing interest rate agreed with the bank?

F1.5. In 2006, did the firm demand more credit without obtaining it?

Then, I estimate the following equation:

$$
\begin{gathered}
(I N V / K)_{i t}= \\
\alpha_{0}+\beta_{0}(I N V / K)_{i t-1}+\beta_{1}(C F / K)_{i t}+\beta_{2} \Delta S A L E S_{i t}+\beta_{3} F I N_{-} C O N_{i}+ \\
\gamma\left((C F / K)_{i t} * F I N_{-} C O N_{i}\right)+\varphi X_{i t-1}+\varepsilon_{i t}
\end{gathered}
$$

where the dependent variable $(I N V / K)_{i t}$ is the ratio of corporate investments to the beginning of the year value of net fixed assets; $(C F / K)_{i t}$ is net income plus depreciation allowances (normalized by the level of net fixed assets at the beginning of the year); $\triangle S A L E S_{i t}$ is the growth rate of sales; FIN_CON $i$ is a dummy variable equal to one if company 
$\mathrm{i}$ is financially constrained, and zero otherwise; $X_{i t-1}$ is a set of firm-specific controls; $\varepsilon_{i t}$ is the error term.

In this model, the effect of cash flow on investment is captured by $\beta_{1}$ for financially unconstrained firms (given $\left.F I N_{-} C O N_{i}=0\right)$ and by $\left(\beta_{1}+\gamma\right)$ for financially constrained businesses. Therefore, I expect $\left(\hat{\beta}_{1}+\hat{\gamma}\right)>\hat{\beta}_{1}$.

Since companies' financial status information is only available for the period 2004-2006, and the GMM estimation technique needs more time observations, I estimate Equation 4 through ols and within-groups estimators. Although I cannot use a broader classification of financing constraints, as Kaplan and Zingales (1997) did, estimation results reported in Table 6 clearly indicate that the positive effect of cash-flow on investment spending is larger for financially constrained $\left(\hat{\beta}_{1}+\hat{\gamma}=0.110+0.211=0.321\right.$, statistically significant $)$ than for financially unconstrained companies $\left(\hat{\beta}_{1}=0.110\right)$.

Given these findings, it can be properly argued that, in the sample under analysis, financially constrained companies do not have significantly lower investment-cash flow sensitivity. Hence, $\hat{\beta}_{1}=\delta(I N V / K)_{i t} / \delta(C F / K)_{i t}$ can be used as a sensible proxy for the existence of financing constraints.

\section{Conclusions}

In this study I have analyzed the role of family ownership structure in exacerbating or mitigating the investment-cash flow dependence of small- and medium-sized enterprises. As different ownership and governance structure should have differently affected the sensitivity of investment spending to internal funds availability, I also examined whether family management and highly concentrated family ownership have influenced the investment-cash flow dependence. Finally, in order to test the validity of the investment-cash flow sensitivity as proxy for the existence of financing constraints, I investigated whether financially constrained companies have had higher investment-cash flow dependence.

Coherently with the current literature on family businesses and investment policies, I have developed the following hypotheses: (H1) Family ownership increases investment-cash flow sensitivity in SMEs; (H2) The higher investment-cash flow sensitivity of family businesses, as compared to non-family firms, is mainly due to the presence of family CEOs and concentrated ownership.

To test these theories, I have analyzed the investment-cash flow sensitivity of 926 Italian SMEs for the period 2004-2013. Qualitative and quantitative information about ownership and management structure have been drawn from the Survey on Italian Manufacturing Firms, 
while balance sheet information have been provided by BvD-AIDA database. By adopting panel data methodology and GMM estimation, I have confirmed the theoretical predictions.

Specifically, estimation results have indicated that family owned firms have larger investment-cash flow sensitivities in comparison with their non-family counterparts. The different investment behavior, moreover, is found to be mainly due to the presence of family CEOs and highly concentrated ownership. As further investigations have confirmed the validity of the investment-cash flow dependence as proxy for the existence of financing constraints, these findings support the idea that family control adversely affect the presence of financing difficulties in small- and medium- sized enterprises.

\section{References}

Almeida, H., Campello, M. and M. S. Weisbach, 2004, The cash flow sensitivity of cash, Journal of Finance 59, pp. 1777-1804.

Anderson, R. and D. Reeb, 2003, Founding family owner and firm performance: Evidence from the S\&P500, Journal of Finance 58, pp. 1302-1328.

Anderson, R., Mansi, S. and D. Reeb, 2003, Founding family ownership and the agency cost of debt, Journal of Financial Economics 68, pp. 263-285.

Andres, C., 2011, Family ownership, financing constraints and investment decisions, Applied Financial Economics 21, pp. 1641-1659.

Barontini, R. and L. Caprio, 2006, The effect of family control on firm value and performance: evidence from continental Europe, European Financial Management 12, pp. 689-723.

Becchetti, L., Castelli, A., and I., Hasan, 2010, Investment-cash flow sensitivities, credit rationing and financing constraints in small and medium-sized firms, Small Business Economics 35, pp. 467-497.

Bertrand, M. and A. Schoar, 2006, The role of family in family firms, Journal of Economic Perspectives 20, pp. 73-96.

Bopaiah, C., 1998, Availability of credit to family businesses, Small Business Economics 11, pp. 75-86.

D'Espallier, B. and A. Guariglia, 2015, Does the investment opportunities bias affect the investment-cash flow sensitivities of unlisted SMEs?, The European Journal of Finance 21, pp. 1-25.

D'Aurizio, L., Oliviero, T., and L. Romano, 2015, Family firms, soft information and bank lending in a financial crisis, Journal of Corporate Finance, http://dx.doi.org/10.1016/i.jcorpfin.2015.01.002.

Faccio, M. and L. H. P. Lang, 2002, The ultimate ownership of Western European corporations, Journal of Financial Economics 65, pp. 365-395.

Fazzari, S. M., Hubbard, R. G. and B. C. Petersen, 1988, Financing constraints and corporate investment, Brookings Paper on Economic Activity, pp. 141-195. 
Gallo, M. A., and A. Vilaseca, 1996, Finance in family business, Family Business Review 9, pp. 387-401.

Goergen, M., and L. Renneboog, 2001, Investment policy, internal financing and ownership concentration in the UK, Journal of Corporate Finance 7, pp. 257-284.

Gugler, K., 2003, Corporate governance and investment, International Journal of the Economics of Business 10, pp. 261-289.

Hadlock, C. J., 1998, Ownership, liquidity, and investment, The Rand Journal of Economics 29, pp. 487-508.

Hoshi, T., Kashyap, A. K. and D. Scharfstein, 1991, Corporate structure, liquidity, and investment: Evidence from Japanese panel data, Quarterly Journal of Economics 106, pp. 33-60.

Hung, J., and Y. Kuo, 2011, The effect of family control on investment-cash flow sensitivity, Applied Financial Economics 21, pp. 897-904.

Kaplan, S. N., and L. Zingales, 1997, Do investment-cash flow sensitivities provide useful measures of financing constraints?, Quarterly Journal of Economics 112, pp. 169-215.

La Porta, R., Lopez-De-Silanes, F. and A. Shleifer, 1999, Corporate ownership around the world, Journal of Finance 54, pp. 471-518.

La Rocca, M., Stagliano, R., La Rocca, T. and A. Cariola, 2015, Investment cash flow sensitivity and financial constraint: a cluster analysis approach, Applied Economics 47, pp. 44424457.

Lopez-Gracia, J., and S. Sánchez-Andújar, 2007, Financial structure of the family business: evidence from a group of small Spanish firms, Family Business Review 20, pp. 269-287.

McConaughy, D. and G. Phillips, 1999, Founders versus descendants: the profitability, efficiency, growth characteristics and financing in large, public, founding-familycontrolled firms, Family Business Review 12, pp. 123-131.

Modigliani, F. and M. H. Miller, 1958, The cost of capital, corporate finance and the theory of investment, American Economic Review 48, pp. 261-297.

Oliner, S. and G. Rudebusch, 1992, Sources of the financing hierarchy for business investment, Review of Economics and Statistics, pp. 643-654.

Pawlina, G., and L. Renneboog, 2005, Is investment-cash flow sensitivity caused by agency costs or asymmetric information? Evidence from the UK, European Financial Management 11, pp. 483-513.

Pindado, J. and C. de la Torre, 2009, The effect of ownership structure on underinvestment and overinvestment: Empirical evidence from Spain, Accounting and Finance 49, pp. 363383.

Pindado, J., Requejo, I., and C. de la Torre, 2011, Family control and investment-cash flow sensitivity: Empirical evidence from the Euro Zone, Journal of Corporate Finance 17, pp. 1389-1409.

Schaller, H.,1993, Asymmetric information, liquidity constraints, and Canadian investment, Canadian Journal of Economics, pp. 552-574.

Schiantarelli, F., and A. Sembenelli, 2000, Form of ownership and financial constraints, panel data evidence from flow of funds and investment equations, Empirica 27, pp.175-192. 
Stacchini, M., and P. Degasperi, 2015, Trust, family businesses and financial intermediaries, Journal of Corporate Finance, http://dx.doi.org/10.1016/j.jcorpfin.2015.01.006.

Villalonga, B. and R. Amit, 2006, How do family ownership, control and management affect firm value?, Journal of Financial Economics 80, pp. 385-341. 


\section{Tables}

Table 1

Distribution of companies by industry sector, ownership type and geographical location

Panel A: Distribution of the full sample by industry sector

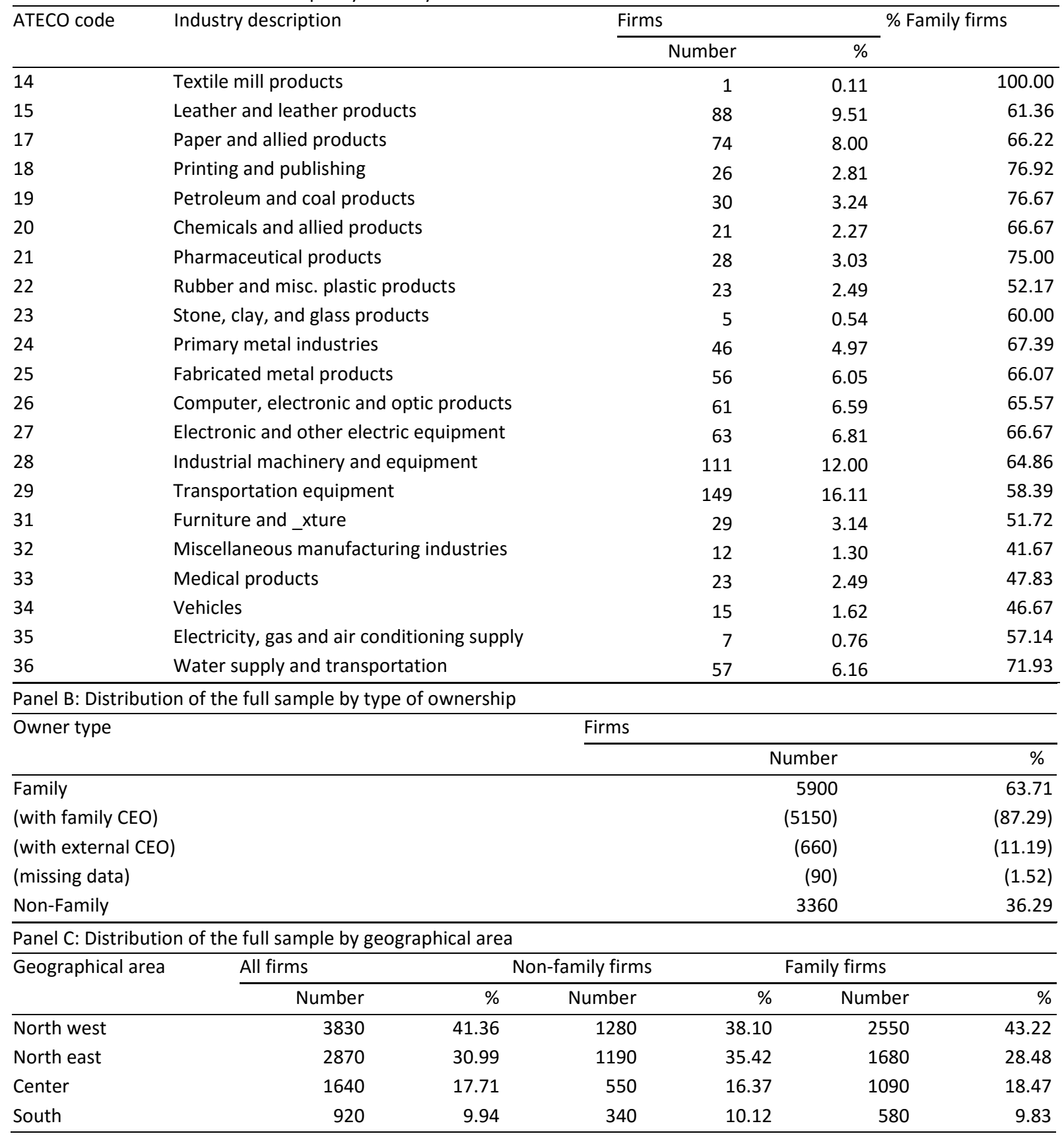


Table 2

\section{Summary statistics}

Panel A: Summary statistics for the full sample

\begin{tabular}{|c|c|c|c|c|}
\hline Variable & Mean & Median & Standard deviation & Observations \\
\hline $\mathrm{INV} / \mathrm{K}$ & 0.131 & -0.009 & 1.113 & 8512 \\
\hline $\mathrm{CF} / \mathrm{K}$ & 0.305 & 0.165 & 0.781 & 8512 \\
\hline$\triangle$ SALES & 0.025 & 0.017 & 0.214 & 8511 \\
\hline DEBT & 0.577 & 0.594 & 0.197 & 9258 \\
\hline $\mathrm{CASH}$ & 0.065 & 0.024 & 0.094 & 8511 \\
\hline
\end{tabular}

Panel B: Summary statistics for family and non-family firms

\begin{tabular}{lrrrrrr}
\hline Variable & \multicolumn{2}{l}{ Non-family firms } & \multicolumn{2}{l}{ Family firms } & \multicolumn{2}{c}{$t$-statistic } \\
\cline { 2 - 6 } & Mean & \multicolumn{2}{c}{ Obs. } & \multicolumn{2}{c}{ Mean } & \multicolumn{2}{c}{ Obs. } \\
\hline INV/K & 0.110 & 3023 & 0.145 & 5309 & 0.034 \\
CF/K & 0.333 & 3023 & 0.289 & 5309 & $-0.045^{* *}$ \\
SSALES & & 0.022 & 3023 & 0.030 & 5308 & $0.008^{*}$ \\
DEBT & & 0.581 & 3359 & 0.574 & 5899 & $-0.007^{*}$ \\
CASH & & 0.057 & 3359 & 0.070 & 5899 & $0.012^{* * *}$ \\
\hline
\end{tabular}

Panel C: Summary statistics for family firms with family and non-family CEOs

\begin{tabular}{llrrrrr}
\hline Variable & \multicolumn{2}{l}{ Non-family CEOs } & \multicolumn{2}{c}{ Family CEOs } & \multicolumn{2}{c}{$t$-statistic } \\
\cline { 2 - 6 } & Mean & \multicolumn{2}{c}{ Obs. } & \multicolumn{2}{c}{ Mean } & \multicolumn{2}{c}{ Obs. } \\
\hline INV/K & 0.171 & 594 & 0.141 & 4634 & $-0.030^{*}$ \\
CF/K & 0.334 & 594 & 0.286 & 4634 & -0.047 \\
SSALES & & 0.022 & 594 & 0.030 & 4633 & 0.008 \\
DEBT & & 0.566 & 660 & 0.574 & 5149 & 0.008 \\
CASH & & 0.064 & 660 & 0.070 & 5149 & $0.006 *$ \\
\hline
\end{tabular}

Panel D: Summary statistics for family firms with high and low family ownership concentration

\begin{tabular}{lrrrrrr}
\hline Variable & \multicolumn{2}{c}{ Low ownership } & \multicolumn{2}{c}{ High ownership } & \multicolumn{2}{c}{$t$-statistic } \\
\cline { 2 - 5 } & Mean & \multicolumn{2}{c}{ Obs. } & \multicolumn{2}{c}{ Mean } & \multicolumn{2}{c}{ Obs. } \\
\hline INV/K & 0.169 & 2187 & 0.129 & 2681 & $-0.040^{*}$ \\
CF/K & 0.280 & 2187 & 0.310 & 2681 & 0.030 \\
$\Delta$ SALES & & 0.023 & 2187 & 0.021 & 2680 & -0.002 \\
DEBT & & 0.581 & 2430 & 0.568 & 2979 & $-0.013^{* *}$ \\
CASH & & 0.073 & 2430 & 0.069 & 2979 & -0.004 \\
\hline
\end{tabular}

Notes: All of the variable are defined in the Appendix. Three, two and one star $\left({ }^{*}\right)$ mean, respectively, 99,95 and 90 percent level of significance. Extreme values are recoded at the $1^{\text {st }}$ and $99^{\text {th }}$ percentiles because of outliers. 
Table 3

Correlation matrix

\begin{tabular}{|c|c|c|c|c|c|c|}
\hline & $\mathrm{INV} / \mathrm{K}$ & $\mathrm{CF} / \mathrm{K}$ & DEBT & CASH & $\triangle$ SALES & \\
\hline INV/K & 1.000 & & & & & \\
\hline $\mathrm{CF} / \mathrm{K}$ & 0.150 & & 1.000 & & & \\
\hline DEBT & -0.011 & & -0.126 & 1.000 & & \\
\hline CASH & 0.001 & & 0.263 & -0.348 & 1.000 & \\
\hline$\triangle$ SALES & 0.025 & & 0.141 & 0.099 & 0.013 & 1.000 \\
\hline
\end{tabular}

Notes: All of the variable are defined in the Appendix. 
Table 4

Family ownership and investment-cash flow sensitivity

\begin{tabular}{|c|c|c|c|c|}
\hline INV/K & $\begin{array}{l}\text { OLS } \\
\text { estimator } \\
(1)\end{array}$ & $\begin{array}{l}\text { Within-group } \\
\text { estimator } \\
(2)\end{array}$ & $\begin{array}{l}\text { First difference } \\
\text { GMM estimator } \\
\text { (3) }\end{array}$ & $\begin{array}{l}\text { System GMM } \\
\text { estimator } \\
(4)\end{array}$ \\
\hline \multirow[t]{2}{*}{$\mathrm{INV} / \mathrm{K}$} & -0.012 & $-0.114 * * *$ & $-0.049 * * *$ & -0.006 \\
\hline & [0.008] & {$[0.006]$} & [0.006] & {$[0.006]$} \\
\hline \multirow[t]{2}{*}{$\mathrm{CF} / \mathrm{K}(\mathrm{a})$} & $0.071 * *$ & $0.131 * *$ & 0.057 & $0.063 *$ \\
\hline & {$[0.031]$} & {$[0.052]$} & {$[0.060]$} & {$[0.032]$} \\
\hline \multirow[t]{2}{*}{ CF/K* FAMILY_FIRM (b) } & 0.276 & $0.356 * *$ & $0.323 * *$ & $0.203 *$ \\
\hline & [0.186] & [0.179] & [0.162] & [0.119] \\
\hline \multirow[t]{2}{*}{$\triangle$ SALES } & $0.112 * *$ & $0.096 * *$ & $0.186 * *$ & $0.100 * *$ \\
\hline & [0.045] & [0.046] & [0.078] & [0.048] \\
\hline \multirow[t]{2}{*}{ DEBT } & $0.002 * * *$ & $0.004 * *$ & -0.005 & $0.003 * *$ \\
\hline & {$[0.000]$} & [0.002] & [0.008] & [0.001] \\
\hline \multirow[t]{2}{*}{ CASH } & $0.595 * * *$ & $1.148 * * *$ & 0.846 & $0.648 * *$ \\
\hline & {$[0.225]$} & [0.296] & [0.702] & {$[0.281]$} \\
\hline \multirow[t]{2}{*}{ FAMILY_FIRM } & -0.009 & & & 0.103 \\
\hline & [0.033] & & & [0.201] \\
\hline Observations & 7398 & 7406 & 6480 & 7398 \\
\hline$H_{0}:(a)+(b)=0$ & 3.40 & 6.59 & 4.14 & 4.87 \\
\hline $\mathrm{AR}(1)$ & & & -1.43 & -1.43 \\
\hline $\operatorname{AR}(2)$ & & & -0.99 & 0.02 \\
\hline Hansen test & & & 256.14 & 305.30 \\
\hline \multicolumn{5}{|c|}{$\begin{array}{l}\text { Notes: The table reports estimation results from Equation } 2 \text {. All of the variables are defined in the Appendix. All regressions } \\
\text { include industry, region and time dummies, not reported for reasons of space. In both GMM estimations, all of the control } \\
\text { variables are treated as endogenous. Three, two and one star }\left({ }^{*}\right) \text { mean, respectively, } 99,95 \text { and } 90 \text { percent level of } \\
\text { significance. Robust standard errors are in brackets. AR(1) and } A R(2) \text { are the Arellano-Bond autocorrelation tests of first and } \\
\text { second order. Hansen test is the over-identifying restrictions test. }\end{array}$} \\
\hline
\end{tabular}


Table 5

Family management, ownership concentration and investment-cash flow sensitivity

\begin{tabular}{|c|c|c|c|c|c|c|c|c|}
\hline $\mathrm{INV} / \mathrm{K}$ & $\begin{array}{l}\text { OLS } \\
\text { estimator } \\
(1)\end{array}$ & $\begin{array}{l}\text { Within-group } \\
\text { estimator } \\
(2) \\
\end{array}$ & $\begin{array}{l}\text { First difference } \\
\text { GMM estimator } \\
\text { (3) }\end{array}$ & $\begin{array}{l}\text { System GMM } \\
\text { estimator } \\
(4) \\
\end{array}$ & $\begin{array}{l}\text { OLS } \\
\text { estimator } \\
(5)\end{array}$ & $\begin{array}{l}\text { Within-group } \\
\text { estimator } \\
(6) \\
\end{array}$ & $\begin{array}{l}\text { First difference } \\
\text { GMM estimator } \\
\text { (7) }\end{array}$ & $\begin{array}{l}\text { System GMM } \\
\text { estimator } \\
(8)\end{array}$ \\
\hline \multirow[t]{2}{*}{$\mathrm{INV} / \mathrm{K}$} & -0.023 & $-0.116 * * *$ & $-0.061 * * *$ & -0.016 & -0.018 & $-0.112 * * *$ & $-0.074 * * *$ & $-0.017^{*}$ \\
\hline & {$[0.016]$} & {$[0.007]$} & {$[0.007]$} & [0.015] & [0.011] & {$[0.012]$} & {$[0.014]$} & {$[0.009]$} \\
\hline \multirow[t]{2}{*}{$\mathrm{CF} / \mathrm{K}(\mathrm{a})$} & -0.021 & 0.070 & 0.060 & 0.047 & 0.541 & 0.522 & 0.552 & 0.440 \\
\hline & {$[0.055]$} & {$[0.071]$} & {$[0.100]$} & [0.063] & [0.494] & [0.394] & {$[0.438]$} & {$[0.374]$} \\
\hline \multirow[t]{2}{*}{ CF/K* FAMILY_CEO (b) } & 0.297 & $0.390^{*}$ & $0.362 * *$ & $0.223^{*}$ & & & & \\
\hline & {$[0.200]$} & {$[0.202]$} & {$[0.180]$} & [0.133] & & & & \\
\hline \multirow[t]{2}{*}{ CF/K* HIGH_OWNERSHIP (b) } & & & & & $0.116 * *$ & $0.218^{* * *}$ & $0.164 * *$ & $0.121 *$ \\
\hline & & & & & [0.058] & [0.070] & [0.082] & {$[0.062]$} \\
\hline \multirow[t]{2}{*}{$\triangle$ SALES } & 0.075 & $0.104^{*}$ & $0.222 * *$ & 0.085 & 0.040 & $0.094 *$ & $0.335^{*}$ & 0.068 \\
\hline & {$[0.050]$} & [0.057] & [0.097] & [0.056] & [0.067] & [0.056] & {$[0.180]$} & [0.065] \\
\hline \multirow[t]{2}{*}{ DEBT } & $0.001 * *$ & 0.004 & -0.011 & $0.004 *$ & $0.002 * *$ & 0.004 & -0.027 & 0.004 \\
\hline & [0.001] & {$[0.003]$} & {$[0.011]$} & [0.002] & [0.001] & [0.003] & {$[0.026]$} & [0.003] \\
\hline \multirow[t]{2}{*}{ CASH } & $0.693 * *$ & $1.328 * * *$ & 1.321 & $0.884 *$ & $0.637 * *$ & $1.206 * * *$ & 1.765 & $0.806^{*}$ \\
\hline & [0.288] & [0.447] & [0.923] & [0.483] & [0.299] & [0.459] & [1.153] & [0.465] \\
\hline \multirow[t]{2}{*}{ FAMILY_CEO } & $-0.104 *$ & & & 0.199 & & & & \\
\hline & {$[0.057]$} & & & [0.146] & & & & \\
\hline \multirow[t]{2}{*}{ HIGH_OWNERSHIP } & & & & & 0.059 & & & $-0.413^{*}$ \\
\hline & & & & & [0.098] & & & [0.232] \\
\hline Observations & 4639 & 4647 & 4066 & 4639 & 4319 & 4327 & 3786 & 4319 \\
\hline$H_{0}:(a)+(b)=0$ & 2.43 & 4.53 & 3.91 & 3.28 & 1.73 & 3.29 & 2.57 & 2.08 \\
\hline$A R(1)$ & & & -1.31 & -1.35 & & & -1.32 & -1.34 \\
\hline$A R(2)$ & & & -1.02 & -0.21 & & & -1.07 & -0.17 \\
\hline Hansen test & & & 277.70 & 359.57 & & & 234.68 & 314.61 \\
\hline
\end{tabular}

Notes: The table reports estimation results from Equations $3 \mathrm{a}$ and $3 \mathrm{~b}$. All of the variables are defined in the Appendix. All regressions include industry, region and time dummies, not reported for reasons of space. In both GMM estimations, all of the control variables are treated as endogenous. Three, two and one star $(*)$ mean, respectively, 99, 95 and 90 percent level of significance. Robust standard errors are in brackets. AR(1) and AR(2) are the Arellano-Bond autocorrelation tests of first and second order. Hansen test is the over-identifying restrictions test. 
Table 6

Investment-cash flow sensitivity and financing constraints

INV/K

OLS

estimator

Within-group

(1)

INV/K

CF/K (a)

10

(0.0

0.015

CF/K* FIN_CON (b)

[0.018]

(2)

$\triangle$ SALES

[0.067]

$0.211^{* * *}$

[0.073]

0.180

[0.142]

$0.001 * *$

[0.001]

$-0.213$

DEBT

0.264

[0.151]

$\mathrm{CASH}$

[0.172]

[0.152]

CASH

$-0.120$

FIN_CON

[0.084]

Constant

$-0.064$

0.242

[0.207]

0.179

[0.142]

[0.059]

$0.448^{* *}$

1686

[0.221]

Observations

0.05

1686

$\mathrm{R}^{2}$

10.36

0.26

$\mathrm{H}_{0}$ : (a)+(b)=0

Notes: The table reports estimation results from Equation 4. All of the variables are defined in the Appendix. All regressions

7.10 include industry, region and time dummies, not reported for reasons of space. Three, two and one star $\left({ }^{*}\right)$ mean, respectively, 99, 95 and 90 percent level of significance. Robust standard errors are in brackets. 


\section{Appendix}

Table A

Variable definitions

\begin{tabular}{|c|c|}
\hline Variable & Definition \\
\hline $\mathrm{INV} / \mathrm{K}$ & $\begin{array}{l}\text { is the ratio between investment spending (INV, computed as the variation in net fixed assets } \\
\text { between time } t \text { and time } t-1) \text { and net fixed assets ( } K \text {, computed at the end of the period). } \\
\text { source: BvD-AIDA. }\end{array}$ \\
\hline $\mathrm{CF} / \mathrm{K}$ & $\begin{array}{l}\text { is the ratio between cash flow (CF, computed as net income plus depreciation allowances) and net } \\
\text { fixed assets ( } \mathrm{K}) \text {. } \\
\text { source: BvD-AIDA. }\end{array}$ \\
\hline$\triangle$ SALES & $\begin{array}{l}\text { is the variation in firm's sales between time } t \text { and time } t-1 \text {. } \\
\text { source: BvD-AIDA. }\end{array}$ \\
\hline CASH & $\begin{array}{l}\text { is cash holdings (cash and marketable securities) scaled by total assets. } \\
\text { source: BvD-AIDA. }\end{array}$ \\
\hline DEBT & $\begin{array}{l}\text { is the debt ratio, computed as total debt over total assets. } \\
\text { source: BvD-AIDA. }\end{array}$ \\
\hline FAMILY_FIRM & $\begin{array}{l}\text { is a dummy variable equal to one if the firm is controlled by an individual or a family owned entity, } \\
\text { and zero otherwise. } \\
\text { "Is your firm directly or indirectly controlled by an individual or a family-owned entity? (i) yes; (ii) } \\
\text { no." } \\
\text { source: Survey on Italian Manufacturing Firms. }\end{array}$ \\
\hline FAMILY_CEO & $\begin{array}{l}\text { is a dummy variable equal to one if the firm is run by its owner or by a family member, and zero } \\
\text { otherwise. } \\
\text { "If your firm is family controlled, who is the CEO? (i) the individual who owns the firm or a member } \\
\text { of the controlling family; (ii) a manager recruited from outside the firm; (iii) a manager appointed } \\
\text { within the firm." } \\
\text { source: Survey on Italian Manufacturing Firms. }\end{array}$ \\
\hline HIGH_OWNERSHIP & $\begin{array}{l}\text { is a dummy variable equal to one if the first shareholder holds more than } 50 \text { percent of equity, and } \\
\text { zero otherwise. } \\
\text { source: Survey on Italian Manufacturing Firms. }\end{array}$ \\
\hline FIN_CON & $\begin{array}{l}\text { is a dummy variable equal to one if the firm suffers from financing constraints, and zero otherwise. } \\
\text { "In 2006, would your firm have wished a larger amount of loans at the prevailing interest rate } \\
\text { agreed with the bank? (i) yes; (ii) no." } \\
\text { "In 2006, did the firm demand more credit without obtaining it? (i) yes; (ii) no." } \\
\text { source: Survey on Italian Manufacturing Firms. }\end{array}$ \\
\hline
\end{tabular}

